\title{
International Migrant Remittances and Saving from Thailand to Neighboring Countries
}

\author{
Thitiwan Sricharoen
}

\section{ABSTRACT}

\begin{abstract}
Remittances are a vital source of income for poor migrant sending countries. The purpose of research is to identify the determinants of remittances of migrant workers in Thailand, that are, Cambodia, Myanmar and Lao migrants. Data collection of 511 migrant workers in central region of Thailand. Methodology uses probit regression analysis. Research results present that the migrants are classified into three groups, which are, first time migration $(45.21 \%)$, second times migration $(26.81 \%)$ and third or more times migration (27.98\%). Determinants of remittance of Cambodia migrants are first time migration, be registered or documented migrant, single status, household size and number of migrating household members in Thailand. Remittance of Myanmar migrants rely on social assistance, be documented migrant, number of months visit home in the last two years, length of stay in Thailand and number of migrating household members in Thailand. For Lao migrants, remittances are influenced by saving, male status, Income, be documented migrant, household size, real estate owned, and burden of family.
\end{abstract}

Keywords: International Migration, Migration, Remittance.
Submitted : June 26, 2021

Published : October 31, 2021

ISSN: 2507-1076

DOI: $10.24018 /$ ejbmr.2021.6.5.958

T. Sricharoen*

Faculty of Economics, Kasetsart

University, Sriracha Campus, Chonburi, Thailand.

(e-mail: thitiwanthitiwan ${ }^{@}$ gmail.com)

*Corresponding Author

\section{INTRODUCTION}

Sending remittance home is very important to the country's economic development. It considers as the component of capital inflows to support and drive the country's economy. Remittances play an important role in reducing poverty, increase the quality of life for households in the country of origin as well as increasing the savings for investment to promote the ability to earn income in the future. Remittance is very important for household member in developing countries. The table compares three countries in terms of the remittance flow from sending country (Thailand) to remittance-receiving countries: Myanmar, Cambodia and Lao, PDR. The table indicates that more Myanmar people work aboard and send remittance than the other two nationalities. In all three countries, Myanmar is the most remittance-receiving country. The total value of remittance from Thailand to Myanmar is nearly $\$ 390$ million, in Cambodia about $\$ 230$ million, and in Lao about $\$ 84$ million. Not much remittance inflow to Lao, PDR compared to the other countries. The World Bank [1] estimates that about 3 million Myanmar migrants abroad in 16 countries. These migrants are estimated to send approximately $\$ 721$ million of remittances into Myanmar in 2017. In Cambodia and Myanmar, remittance inflow account for approximately 5.6\% and $4.6 \%$ of Cambodia and Myanmar's GDP that year. On the other hand, remittance inflow in Lao, PDR was not as much as in the other countries, with only $1.3 \%$ of Lao's GDP (Table I).
TABLE I: BILATERAL REMITTANCE ESTIMATES FOR 2017 USING MigRATION STOCKS, HOST COUNTRY INCOMES, AND ORIGIN COUNTRY INCOMES (MILLIONS OF US\$) (APRIL 2018 VERSION)

\begin{tabular}{cccc}
\hline \hline & \multicolumn{3}{c}{ Remittance-receiving country (across) } \\
\cline { 2 - 4 } & \multicolumn{4}{c}{ Myanmar } & Cambodia & Lao, PDR \\
\hline Remittance-sending country (down) \\
Thailand & 389 & 230 & 84 \\
World & 721 & 386 & 124 \\
\hline Remittance from sending country to receiving country as \% of world \\
\multicolumn{5}{c}{ \% of GDP } & 53.95 & 59.59 & 67.74 \\
\hline \hline
\end{tabular}

S. Turnell, A. Vicary, and W. Brandford [3] indicate that "informal remittances from overseas were three to four times higher than formal remittances". The three pie charts compare the main source countries for estimated remittance flows to Myanmar, Cambodia and Lao, PDR in the year 2017. For three charts of the remittance inflow, it is evident that Thailand was significant source of remittance in its large proportion of remittance source. The large proportion of the total Myanmar and Cambodia migrant population to Thailand lead these countries has emerged as top countries for receiving remittances from Thailand. According to Myanmar, the total remittances from Thailand alone is $\$ 389$ million. The next biggest category is the remittance from Saudi Arabia, amounting for $\$ 196$ million. In addition, United States, Bangladesh, Malaysia, and Pakistan are also the main destination for Myanmar workers. Tuning on to the chart of Cambodia, remittances outflows from some major sending countries to Cambodia are mainly from Thailand, amounting for $\$ 230$ million, following by United States ( $\$ 80$ million) and France (\$26 million), respectively. Finally, in the case of Lao, PDR, main source of remittance inflow to the country 
are from Thailand and United States. Overall, when compare the main sources of remittances between three countries, it is interesting that Myanmar workers migrate into many different countries. It represents that remittance inflow to Myanmar are greater than other countries. Consequently, this research has the purpose to study the remittance and saving behavior of Myanmar, Cambodia and Lao, PDR migrants for the country's economic development (Fig. 1).
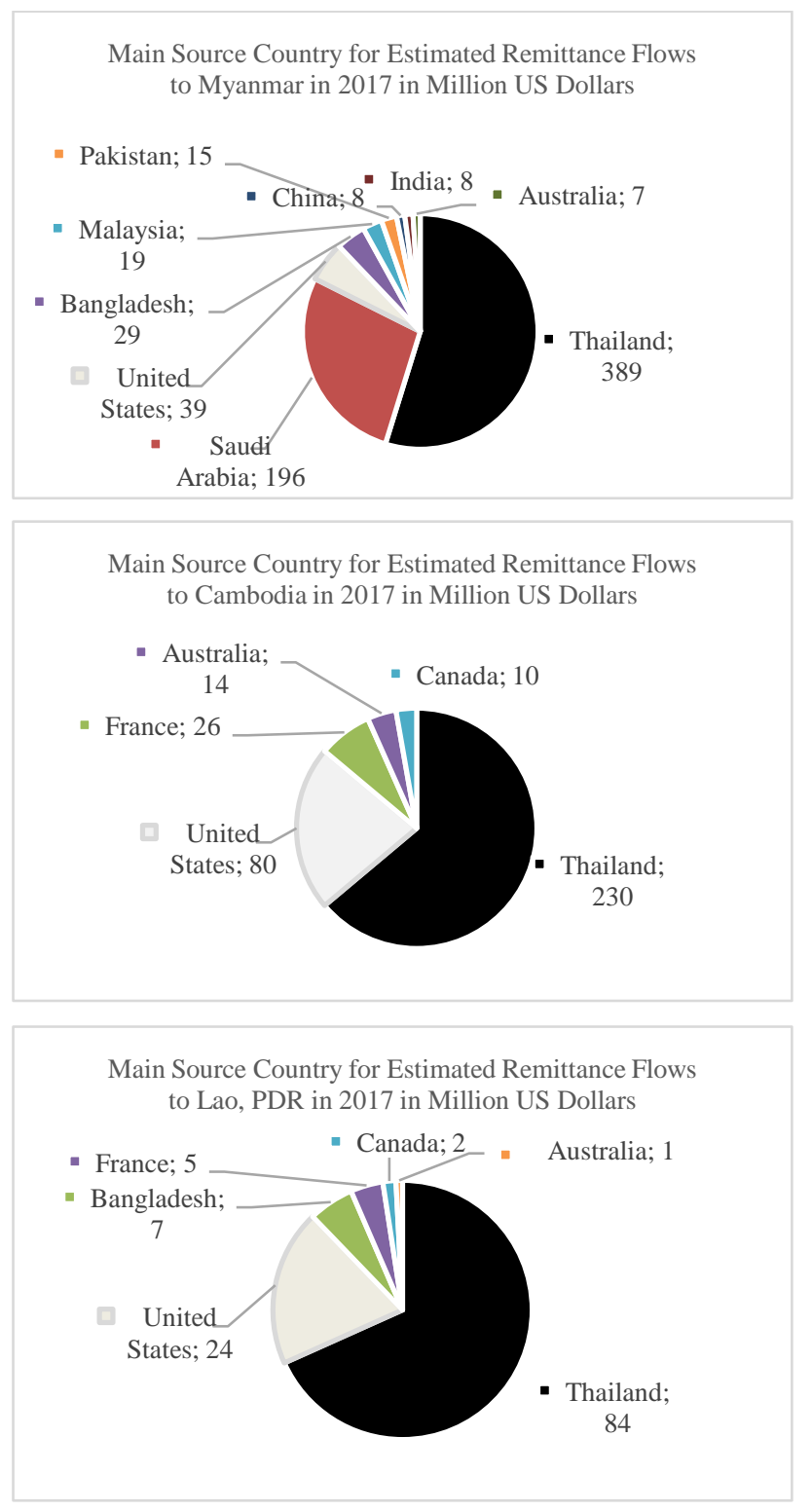

Fig. 1. Main Source Country for Estimated Remittance Flows to Myanmar, Cambodia and Lao, PDR in 2017 in Million US Dollars. Source: World Bank [1].

Remittances tend to increase household aggregate wealth and reduce poverty [4]. Therefore, the purpose of this study is to analyze remittance behavior in order to get policy recommendations encourage more money transfers to alleviate poverty. This study has main questions: What determines the number of remittances? Which factors influence the remittances of Myanmar, Cambodia, and Lao migrants? What is the difference between migration group, which are, first time migration, second time migration, and third or subsequent migration?

\section{LITERATURE REVIEWS}

Literature reviews main research related to migration and remittance. E. Holst and M. Schrooten [5] study on migration and money what determines remittances? Evidence from Germany. Determinant of remittance use cross-sectional data from German SOEP Data in 2004 by surveying and asking questions about socio-economic status and demographic characteristics. This research aims to identify determinant of personal remittance and remittance behavior in Germany by analyzing probability of remittance. The study concentrates on personal background of migrants. Analytical tool is probit regression analysis. Research results show about 1) the degree of integration into German society matters. 2) the probability to remit is not dominated by income.3) foreigners living in Germany are not a homogenous group concerning their remittance behavior: people with Turkish and former Yugoslavian citizenship, who are facing a comparable strong pressure for return migration, remit significantly more than others. Remittance is the most important. Moreover, legal status of migrants has an influence on cross border remittance behavior and incentive of remittance come from globalization. Determinants of remittance of foreigners are age, age square, female gender, marriage status, being employment, social assistance, being unemployment, income less than 900-euro, income between 900-1,200-euro, income between 1,200-1,600 euro, being foreigner status, being Turkish, being Yugoslavia person, being other nationalities, household size, belonging own property, number of years living in Germany, number of times visit home in last two year and others control variables. Variables that influence on remittance at the significant of $\mathrm{p}<0.01$ are being Yugoslavia person, household size, number of years living in Germany and number of times visiting home in last two years. Another is research of L. Deelen and P. Vasuprasat [6], research on migrant workers' remittances from Thailand to Cambodia, Lao PDR, and Myanmar. This study collect data from interview and do focus group discussion migrants to Thailand about the remittance of migrants in Thailand and the receiving money of household in Cambodia and Lao. In Thailand, 356 migrants are interviewed, classified by industrial sector, construction sector, housework, and fishery sector in different area. In Lao, 200 households are interviewed in Khammouane, Savanakhet, Saravan and Champasak province. In Cambodia, there are the interviews of 200 households in Banteay Meanchey, Battambang, Pursat, Koh Kong and Kampot provinces. Research finds that remittance through informal channel is popular. Migrants are not sent remittance to friends or family member through formal channel such as Western Union, MoneyGram, although there is widely branch of this business in Cambodia and Lao. It is because of high cost. Moreover, people lack of information, and satisfy to send remittance by themselves. The receiver in rural Cambodia, Lao and Myanmar lack of opportunity and capacity to invest. The share of remittance uses for household basic needs such as household expense, transportation, which not help to make better socioeconomic status of household. Remittance is not use for investment and develop local economy. Some migrants in Thailand hold banking book account but there is a small number of them remit money through formal channel. This study recommends promote migrants to access financial service. The registered 
migrants can open banking book. Bank should reduce money transferring cost. Government should protect the rights of foreigners to carry money back home. Suggestion in case of Cambodia and Lao, migrants should study information about money transaction before travelling. Government should promote deposit-taking microfinance institutions, promote to set village bank, develop transfer money business, relax foreign account for migrants, promote ATM network, electronic money and promote to use formal financial service. The next work is research of S. H. Lee, N. Sukrakarn, and J.Y. Choi [7] research on repeat migration and remittances: evidence from Thai migrant workers by Asian Research Center for Migration, Chulalongkorn University. Research finding that although there was research on repeat migration in United State and Europe, but there is no empirical research related to Asia. This research has the purpose to analyses the remittance and saving behavior of repeat migration by interviewing 519 Thai migrants in 6 destinations, that are, Taiwan, Hong Kong, Israel, Brunei, Singapore, and South Korea. Research results find that the repeat migrants are the specific group. Male migrants have tendency to repeat migration compare with female migrants. Repeat migration is correlated with age, which the U-shape downward curve. Repeat migrants are likely to less remit money to home country but they are likely to save. First time migrants are likely to send remittance back to Thailand. Factors use to run remittances determinants are number of time migration, second time migration, third-or subsequent migrants, age, age and number of migration, age and second time migrants, age and third-or subsequent migrants, male, junior high, high school, more than high school, documented worker, married status without children, married status with children, be migrants in Hong Kong, be migrants in Brunei, be migrants in other countries, work in service sector and work in labor sector [7]. Send remittances are different between first-time, second time, third-or subsequent migrants. For example, remittance determinants of first-time migrants are number of migrations, age, high school, be migrant in Hong Kong, be migrant in other countries, and work in service sector. Then, R. Akee and D. Kapur [8] study about Myanmar remittances. Data review from various research to identify the remittance behavior after the revolution. Result show that there are 3.1 million Myanmar live aboard. The remit 3.5 billion dollar to Myanmar or about 5 percent of GDP. This amount is not including the informal or non-registered migrants. If it includes, it estimates that the remit to Myanmar is about 8 billion dollar or about 13 percent of GDP. Household survey data indicate that they receive money through informal channel, and they use money for basic needs. Most migrants care of transfer cost and they are not trust on formal channel that limit the transfer big amount of money. Suggestions of study are: 1) Setting the committee to manage information to sustain the migration and analyses the remittance, 2) reduce the profit making through informal channel in remitting money by reduce tariff and quota and accept floating currency exchange rate, 3 ) develop financial service through mobile to allow borrow money, saving and do cross border transaction, 4) link the potential migrants to create opportunity to work aboard through the legal agency, 5) train the migrants about the financial knowledge, destination countries, labor rights, 6) government should support to people to migrate and register banking, 7) develop new financial product to reduce transaction cost. Next, OECD [9] illustrates determinants of remittance classify in these factors: (1) Migrants' ability: income, savings, motivation to remit, duration of migration (how long do migrants intend to stay abroad), temporarily or permanently migration. (2) Family situation of migrants: status (single, married with or without children). (3) Network effects: move alone or move with family members, keeping attachments to children or those left behind. After that, J. Carling [10] studied on the determinants of migrant remittances. Possible influences on remittance-sending are disaggregated into nine domains. Potential remittance sender: (1) Individual and household characteristics, (2) Environment of potential senders, (3) other (potential) remittance receivers. Potential remittance receiver: (4) Individual and household characteristics, (5) Environment of potential receivers, (6) other (potential) remittance senders, (7) Potential sender's assets in area of origin. Linkage between countries: (8) Country-to-country remittance corridor, (9) Sender-receiver relationship (including family migration history). Next, U. Oser. [11] studied determinants of migrant's remittances: (1) Personal characteristics: age, age square, low education, high education, household size, nationality (Greece, Italy, Yugoslavia, Spain), male. (2) Indicator of assimilation: spouse living in home country, children in home country, years in Germany, remigration within one-year, temporary migration, school attendance in Germany. (3) Income variable: Net monthly family income. Finally, D.A. Grigorian, and T.A. Melkonyan [12] viewed that determinants of remittance consist of: (1) age of the household head (and its squared value), (2) average age of working age members of the household (and its squared value), (3) dummy for male household head; (4) percent of household members with post-secondary education, (5) percent of household members above 64, (6) percent of household members under 6 , (7) percent of women in the household, (8) size of the household, and (9) dummy variables to distinguish the rural and urban areas from the capital.

\section{ReSEARCH Methodology AND dATA Collection}

This paper uses the 2018 survey data of 511 migrant workers from Myanmar, Cambodia and Lao, who work in Thailand. The main objective of research is to find out the determinants of remittance of workers from the above countries. First part of questionnaire relates to household background of migrants. Second part contains information about aid and demand for social welfares. The final part includes information on the decision to return, migration experiences, remittances, and savings. Research methodology applies probit regression analysis. The explanatory variables categorize into five categories, (1) repeat migration, (2) demographic characteristics and human capital, (3) attachment to the hosting country, (4) attachment to the home country, and (5) other control variables such as occupation of migrants and a set of dummy variables. We use three variables as indicators of repeat migrants. The first indicator is the number of migrations. The second and third are indicator of repeat migrants (i.e., not first-time migrant). 


\section{RESEARCH FINDINGS}

Research results are classified into descriptive analysis on migrant workers' characteristics and quantitative analysis on migrant's remittances and saving. Table II is descriptive analysis of variables presenting in percentage and mean values. All variables include in the model affect the decision to migrate and remit in the literature. This study uses a binary dependent variable for migrants' remittance and saving behavior, respectively, indicating whether migrants regularly remit to their family residing in the home country or save for themselves. The migrants are classified into three groups, which are, first time migration $(45.21 \%)$, second times migration $(26.81 \%)$ and third or more times migration $(27.98 \%)$. Repeated migrants who are not first-time migrant, are a highly specific group with $54.74 \%$. According to the willingness to migrate again in the future, the proportion of migrants who would like to go abroad again rises with the first-time migrants. About $58 \%$ of first-time migrants would like to go abroad again, compared with $30 \%$ of second time migrants. This percentage is even higher (33\%) for third-time migrants, suggesting that repeat migration may depend on past migration experience. Note to remittance and saving, first-time migrants are most likely to send remittances home while working in Thailand, accounting for 2,826 Baht per month. However, this number decrease with the second-time migrants send remittances about 2,331 Baht per month, whereas third-time migrants send remittance around 2,560 Baht per month. Saving behavior is similar between first-time migrants and second-time migrants. For first-time and second-time migrants save a portion of their earnings. However, this number dramatically increases to $50 \%$ in the cases of third and subsequent times. The indicator of debts owed is different from the pattern of remittances. Third-time or more times migrants are more likely to have debts and also more likely to send remittances to pay those debts. The inclusion of migrant's age and gender are as demographic characteristics. The average age of migrants is around 28 years for first-time migrants, 31 years for second-time migrants, and 33 years for third (or subsequent) time migrants. Average age of first-time migrants is lowest among these groups. First time migrants and third- or subsequent time migrants are more likely to be female. While about $51 \%$ of second time migrants are male, compared with their female counterparts. The human capital variable is measured by three educational attainment dummy variables: one for below primary school attainment, and the other for primary and secondary school attainment. Most of first-time migrants have an education below primary school with $38.96 \%$. Most of the repeat migrants have a primary school diploma. Refer to social status, almost all of the migrants are employed. About $25 \%$ of migrants receive social assistance. They earn an average income of 9,554 Baht per month. About the attachment to the hosting country, most of migrants are documented workers. For the attachment to the home country, the third (or subsequent) time migrants have at least one child in their family. First time migrants are more likely to be single with $55.41 \%$, whereas the repeat migrants are more likely to be married. Second time migrants and third- or subsequent time migrants are more likely to be married with kids account for $53.28 \%$ and $69.93 \%$, respectively. Migrants mostly have an average of three family members in Thailand.
When compare to three migrant groups, first time migrants are more likely not response on family expenses. However, most of second time and third time migrant groups response some part of family expenses. Regarding to the integration, average household size of migrant is 5 persons. The third- (or subsequent) time migrants are mostly occupying the land and real estate, amounting for $46 \%$. Average year of staying in Thailand of all groups are 6 years. It is about $70 \%$ of repeat migrants visit home in last 2 years. Source countries are different from each group. Most of the first-time migrants come from Myanmar (35.5\%), while Cambodian migrants are more likely to be the repeat migrants, amounting for $50 \%$. The types of works may have some influence on the intent to remit and save. Migrant's work is concentrated in the labor and service industry. A majority of first-time migrants are working in service sector as maids, employee in restaurants, whereas most repeat migrants are working in construction sector as laborers.

As in Fig. 2, it describes the relationship of age of migrant and repeat migration. First time migration is range on the left category. Graph of first-time migration skewed towards younger people. In the middle graph explain the second time migration. The majority of those who migrate for the second time are middle aged people. The graph to the far right is flat, showing people migrating repeatedly three or more times, most of them is older than middle age.

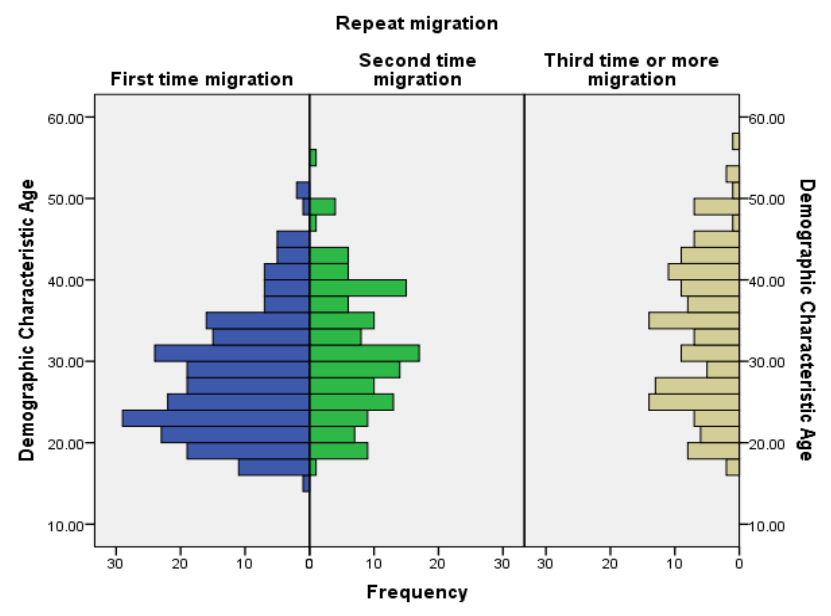

Fig. 2. Relation of Demographic Characteristic Age and Repeat Migration.

According to Fig. 3, which explains the relationship of send remittance and repeat migration. Migrant who migrates for the first time sent the most remittances, but remittances drop for the repeat migrants. There is a strong negative age dependence of remittances. It can be implied from the results that repeat migrants tend to be older, as a result, older migrant workers are less likely to send remittances.

Refer to Fig. 4, that give an interesting result that migrants residing from Cambodia are much more likely to send remittances than migrants from Myanmar and Lao. Cambodians and Burmese that move for the first time are the group of people who send the most money back. Burmese and Laotian people who migrate repeatedly are those who send very little money home. 
TABLE II: DESCRIPTIVE ANALYSIS OF VARIABLES

\begin{tabular}{|c|c|c|c|c|}
\hline & Total & $\begin{array}{l}\text { First- } \\
\text { time } \\
\text { migrant }\end{array}$ & $\begin{array}{l}\text { Second- } \\
\text { time } \\
\text { migrant }\end{array}$ & $\begin{array}{c}\text { Third-or } \\
\text { sub- } \\
\text { sequence } \\
\text { migrant }\end{array}$ \\
\hline \multicolumn{5}{|l|}{ Repeat migration } \\
\hline First time (\%) & 45.21 & & & \\
\hline Second time $(\%)$ & 26.81 & & & \\
\hline Third or more $(\%)$ & 27.98 & & & \\
\hline Will Migrate again (\%) & 43.44 & 57.58 & 30.66 & 33 \\
\hline \multicolumn{5}{|l|}{ Savings and remittances } \\
\hline $\begin{array}{l}\text { Remittances (Baht per } \\
\text { month) }\end{array}$ & 2,627 & 2,826 & 2,331 & 2,560 \\
\hline Savings (Baht) & 1,161 & 924 & 877 & 1,815 \\
\hline Debt (Baht) & 2,078 & 1,372 & 2,358 & 2,951 \\
\hline \multicolumn{5}{|l|}{ Demographic characteristics } \\
\hline Age (years) & 30 & 28 & 31 & 33 \\
\hline Male $(\%)$ & 46.18 & 41.13 & 51.09 & 49.65 \\
\hline Female $(\%)$ & 53.82 & 58.87 & 48.91 & 50.35 \\
\hline \multicolumn{5}{|l|}{ Human capital } \\
\hline $\begin{array}{l}\text { Below primary school } \\
(\%)\end{array}$ & 34.25 & 38.96 & 25.55 & 34.97 \\
\hline Primary school (\%) & 42.86 & 35.93 & 54.74 & 42.66 \\
\hline $\begin{array}{l}\text { Secondary School and } \\
\text { above }(\%)\end{array}$ & 22.90 & 25.11 & 19.71 & 22.38 \\
\hline \multicolumn{5}{|l|}{ Social status } \\
\hline $\begin{array}{l}\text { Unemployed(yes=1) } \\
(\%)\end{array}$ & 1.37 & 0.43 & 2.19 & 2.10 \\
\hline $\begin{array}{l}\text { Receive social } \\
\text { assistance }(\text { yes }=1)(\%)\end{array}$ & 25.44 & 29.87 & 21.17 & 22.38 \\
\hline $\begin{array}{l}\text { Income (Baht per } \\
\text { month) }\end{array}$ & 9,554 & 9,630 & 9,378 & 9,600 \\
\hline \multicolumn{5}{|c|}{ Attachment to the hosting country } \\
\hline $\begin{array}{l}\text { Documented worker } \\
(\%)\end{array}$ & 94.32 & 90.91 & 99.27 & 95.10 \\
\hline \multicolumn{5}{|c|}{ Attachment to the home country } \\
\hline $\begin{array}{l}\text { Number of children } \\
\text { (person) }\end{array}$ & 0.84 & 0.50 & 0.90 & 1.36 \\
\hline Single (yes=1) $(\%)$ & 40.51 & 55.41 & 33.58 & 23.08 \\
\hline Married (yes=1) $(\%)$ & 59.49 & 44.59 & 66.42 & 76.92 \\
\hline $\begin{array}{l}\text {-Married, but no kids } \\
(\text { yes }=1)(\%)\end{array}$ & 13.31 & 14.29 & 13.13 & 6.99 \\
\hline $\begin{array}{l}\text {-Married with kids } \\
(\text { yes }=1)(\%)\end{array}$ & 47.55 & 30.30 & 53.28 & 69.93 \\
\hline \multicolumn{5}{|c|}{ Family members in Thailand (persons) } \\
\hline & 3 & 2 & 3 & 3 \\
\hline \multicolumn{5}{|l|}{ Burden of family } \\
\hline $\begin{array}{l}\text {-Not response on family } \\
\text { expense }(\%)\end{array}$ & 29.94 & 40.69 & 27.01 & 16.8 \\
\hline $\begin{array}{l}\text {-Response some family } \\
\text { expense }(\%)\end{array}$ & 55.19 & 42.86 & 66.42 & 62.9 \\
\hline $\begin{array}{l}\text {-Response full family } \\
\text { expense }(\%)\end{array}$ & 14.87 & 16.45 & 6.57 & 20.3 \\
\hline \multicolumn{5}{|l|}{ Integration } \\
\hline $\begin{array}{l}\text { Household size } \\
\text { (persons) }\end{array}$ & 5 & 4 & 5 & 5 \\
\hline $\begin{array}{l}\text { Real estate owned } \\
(\text { yes }=1)(\%)\end{array}$ & 37.18 & 38.53 & 25.55 & 46.15 \\
\hline $\begin{array}{l}\text { Average year of staying } \\
\text { in Thailand (years) }\end{array}$ & 6 & 6 & 6 & 7 \\
\hline $\begin{array}{l}\text { Visit home in last } 2 \\
\text { years (yes }=1)(\%)\end{array}$ & 53.23 & 29.00 & 72.99 & 73.43 \\
\hline $\begin{array}{l}\text { Expected time to stay in } \\
\text { Thailand (years) }\end{array}$ & 8 & 8 & 9 & 8 \\
\hline \multicolumn{5}{|l|}{ Source countries } \\
\hline Cambodia (\%) & 41.29 & 31.17 & 50.36 & 48.95 \\
\hline Myanmar (\%) & 29.35 & 35.50 & 20.44 & 27.97 \\
\hline Lao $(\%)$ & 29.35 & 33.33 & 29.20 & 23.08 \\
\hline \multicolumn{5}{|l|}{ Industry } \\
\hline Manufacturing (\%) & 15.66 & 18.18 & 15.33 & 11.89 \\
\hline Service $(\%)$ & 38.16 & 47.62 & 34.31 & 26.57 \\
\hline $\begin{array}{l}\text { Labor (mostly in } \\
\text { construction) }(\%)\end{array}$ & 40.30 & 26.84 & 47.45 & 54.55 \\
\hline Agriculture (\%) & 5.89 & 7.36 & 2.92 & 6.99 \\
\hline Number of observations & 511 & 231 & 137 & 143 \\
\hline Number of observation (\%) & 100 & 45.21 & 26.81 & 27.98 \\
\hline
\end{tabular}

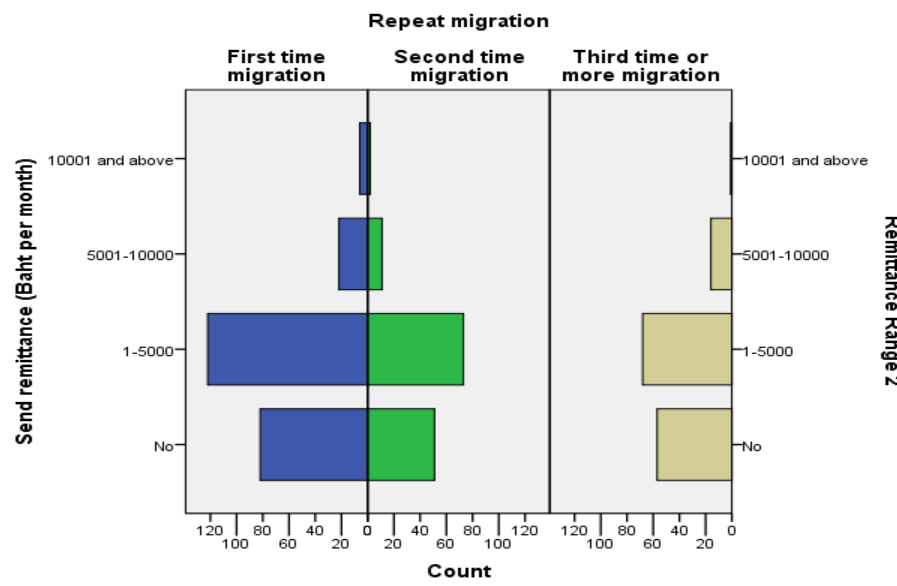

Fig. 3. Relation of Send Remittance and Repeat migration.

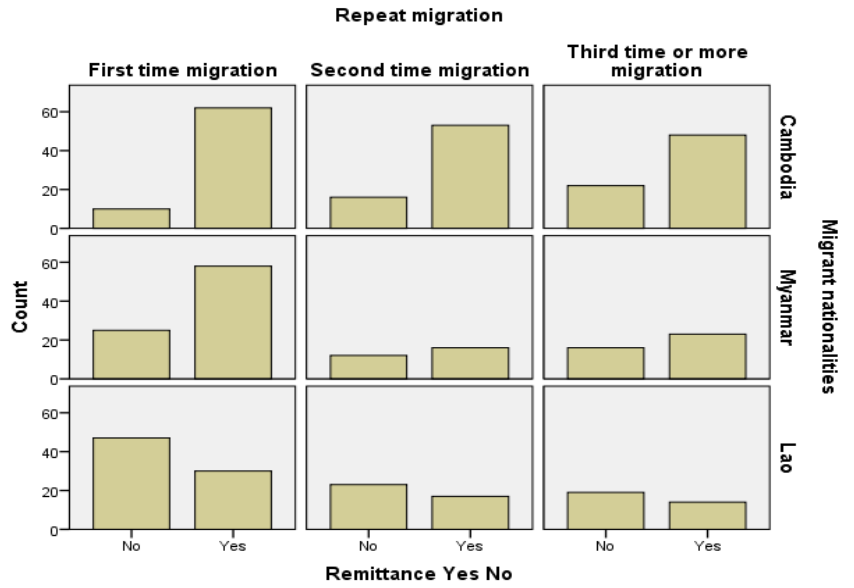

Fig. 4. Repeat Migration, Migrant Nationalities and Remittance.

Note to Fig. 5, which is the analysis of repeat migration, migrant nationalities, and plan to migrate again in the future. Cambodians who have previously migrated are expected not migrate elsewhere in the future since individual migrant prefers that family members stay in Thailand, rather than emigrating abroad. Contrary to the group of all nationalities migrants who migrate for the first time have a pretty much desire to migrate again in the future.

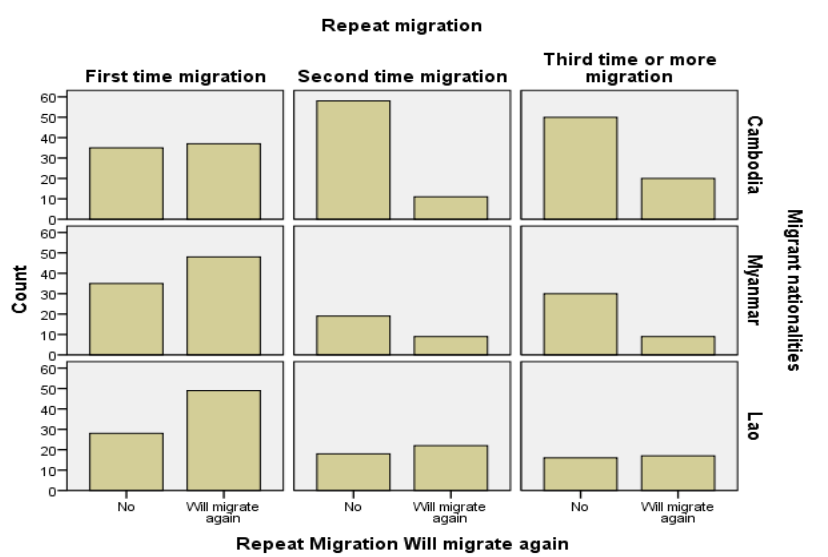

Fig. 5. Repeat Migration, Migrant Nationalities and Plan to Migrate Again. Source: Own calculation.

Table III discuss the regression results of the estimates for remittances classified by nationalities. The first equation is the estimation of sending remittances of all migrant's 
nationalities. The variables that have the influence on remittances in the same way are the variables of being Cambodia migrants, Burden of family, social assistance, being Myanmar migrant and household size, respectively. On the other hand, the variables that effect on remittances in the opposite ways are attain below primary school, education (in year), real estate owned, and number of migrating household members in Thailand, respectively. The results show that those who finished below primary school are more likely to send remittances, compared with those who finished above primary school.

TABLE III: PROBIT ESTIMATES FOR REMITTANCES CLASSIFIED BY NATIONALITIES

\begin{tabular}{|c|c|c|c|c|}
\hline & $\begin{array}{c}\text { Send } \\
\text { remittances } \\
\text { (Total) }\end{array}$ & $\begin{array}{c}\text { Send of } \\
\text { remittance } \\
\text { Cambodian } \\
\text { migrants }\end{array}$ & $\begin{array}{l}\text { Send of } \\
\text { remittance } \\
\text { Myanmar } \\
\text { migrants }\end{array}$ & $\begin{array}{l}\text { Send of } \\
\text { remittance } \\
\text { Lao } \\
\text { migrants }\end{array}$ \\
\hline & Equation1 & Equation2 & Equation 3 & Equation4 \\
\hline Saving & & & & $\begin{array}{c}-0.793 \\
(0.000)\end{array}$ \\
\hline $\begin{array}{l}\text { First time } \\
\text { migration }\end{array}$ & & $\begin{array}{c}0.763 \\
(0.004)\end{array}$ & & \\
\hline Male & & & & $\begin{array}{l}-0.660 \\
(0.050)\end{array}$ \\
\hline $\begin{array}{l}\text { Education } \\
\text { (In year) }\end{array}$ & $\begin{array}{l}-0.622 \\
(0.001)\end{array}$ & & & \\
\hline $\begin{array}{l}\text { Below primary } \\
\text { school }\end{array}$ & $\begin{array}{l}-0.846 \\
(0.003)\end{array}$ & & & \\
\hline $\begin{array}{c}\text { Social } \\
\text { assistance(yes=1) }\end{array}$ & $\begin{array}{c}0.586 \\
(0.000)\end{array}$ & & $\begin{array}{l}0.968 \\
(0.003)\end{array}$ & \\
\hline Income(amount) & & & & $\begin{array}{l}0.0001 \\
(0.005)\end{array}$ \\
\hline Register migrant & & $\begin{array}{l}-0.758 \\
(0.028)\end{array}$ & $\begin{array}{l}-1.405 \\
(0.017)\end{array}$ & $\begin{array}{l}3.163 \\
(0.000)\end{array}$ \\
\hline Single & & $\begin{array}{l}-0.553 \\
(0.033)\end{array}$ & & \\
\hline Household size & $\begin{array}{c}0.096 \\
(0.002)\end{array}$ & $\begin{array}{c}0.202 \\
(0.005)\end{array}$ & & $\begin{array}{c}0.131 \\
(0.005)\end{array}$ \\
\hline $\begin{array}{l}\text { Real estate owned } \\
\quad(\text { yes }=1)\end{array}$ & -0.360 & & & -1.015 \\
\hline & $(0.009)$ & & & $(0.011)$ \\
\hline Visit home in $\mathrm{tl}$ & last 2 years $(\mathrm{m}$ & nths) & $\begin{array}{c}-0.074 \\
(0.150)\end{array}$ & \\
\hline $\begin{array}{l}\text { Length of } \\
\text { stay in }\end{array}$ & & & -0.072 & \\
\hline Thailand & & & $(0.049)$ & \\
\hline Cambodia $($ yes $=1$ ) & $\begin{array}{c}0.967 \\
(0.000)\end{array}$ & & & \\
\hline Myanmar (yes=1) & $\begin{array}{c}0.404 \\
(0.031)\end{array}$ & & & \\
\hline Number & $\begin{array}{l}\text { migrating hou } \\
-0.221 \\
(0.000)\end{array}$ & $\begin{array}{l}\text { sehold membe } \\
-0.211 \\
(0.003)\end{array}$ & $\begin{array}{l}\text { ars in Thailand } \\
-0.284 \\
(0.000)\end{array}$ & \\
\hline $\begin{array}{l}\text { Burden of } \\
\text { family }\end{array}$ & $\begin{array}{c}0.684 \\
(0.000)\end{array}$ & & & $\begin{array}{c}2.044 \\
(0.000)\end{array}$ \\
\hline cons & $\begin{array}{c}0.237 \\
(0.657) \\
\end{array}$ & $\begin{array}{c}0.545 \\
(0.040) \\
\end{array}$ & $\begin{array}{c}1.806 \\
(0.000) \\
\end{array}$ & $\begin{array}{c}-5.044 \\
(0.000)\end{array}$ \\
\hline $\begin{array}{c}\mathrm{N} \\
\text { Pseudo } \mathrm{R}^{2}\end{array}$ & $\begin{array}{c}511 \\
0.238\end{array}$ & $\begin{array}{c}211 \\
0.101\end{array}$ & $\begin{array}{c}150 \\
0.267\end{array}$ & $\begin{array}{c}150 \\
0.569\end{array}$ \\
\hline
\end{tabular}

Source: Own calculation.

Note: Value in bracket is $\mathrm{P}>|\mathrm{z}|$.

The next equation concentrates on send remittance of Cambodian migrants. Result reveals that remittance has a positive correlated with first time migration and household size. This finding is consistent with the notion that first time migrant workers remit most of their earned income in Thailand to Cambodia, but less likely to save, compared with repeat migrants. Another variable is household size that has an effect on remittance. Migrants with large household size have more tendency to send remittances to support their household. However, remittance has a negative correlated with the variables of documented migrant, single status and number of migrating members in Thailand. The reason is the cost of registering foreign workers is high, so they have less amount of money to send back home. For the status, the single one who is not response on family expenses, is less likely to send remittances. The last variable is family member in destination country, it indicates that the more family members living together in Thailand, the less remittances are sent.

The analysis of the third equation is related to Myanmar remittance behavior. The study shows that send remittance of Myanmar migrants is strongly positive correlated with social assistance, but it is negative correlated with documented migrant, number of months visit home in last two years, length of stay in Thailand and number of migrating household members in Thailand. For the correlation of social assistance and remittance, receiving social assistance has a great influence on the remittances of Burmese people because it helps them to save money, resulting in having a lot of money left for repatriation. The next is the explanation about the variables which have negative correlate with remittance. The documented migrant play safe for sustain their living aboard by reducing cost of living and also remittance. Another variable is the number of months visit home in last two years, Burmese people often take money home to reduce transaction cost. The more they go home and stay home for many months, the less money remit. Further is the variable of length of stay in Thailand. The migrants who have a longer stay in Thailand are expected to decrease to send remittance if they plan to settle down in a foreign country. Lastly, the number of migrating household members in Thailand has an effect on the remittance in opposite way. As the number of migrants from the origin household increases, the migrant will be less likely to send remittances because close relatives live in the sending country together already.

The fourth equation deals with send remittance of Lao migrants. Remittance is correlated in orderly with documented migrant, burden of family, household size, amount of income in the positive way. The first variable is explained by being documented migrant. In the case of Lao migrants, being documented migrants may lead them earn more income enough to send more remittances. The second variable devote to family burden. For foreigners who have a lot of family responsibilities, they have to send money back regularly. The third influential variable is household size. Migrants in large families tend to think about the existence of people at home, then they will send a lot of money back to support family's living cost. The fourth variable is discussed about income, it is certainly that remittances increase with per capita income, but in this case, income have no significant impact on remittances. On the other way, send remittance of Lao migrants has a negative correlated with real estate owned, saving, and male status, respectively. Migrants who have their own home in their hometown show that they have a certain level of wealth, so they will send less money back home. For saving, the migrants who are more likely to save, they are less likely to send remittances due to saving is the priority source to sustain their future life. Finally, the status of migrants, Laotian male migrants are less likely to send remittances because male normally response on housing cost in Thailand and may spend high for social cost. 
TABLE IV: PROBIT ESTIMATE OF REMITTANCES CLASSIFIED BY NUMBER OF MigRATING TIMES

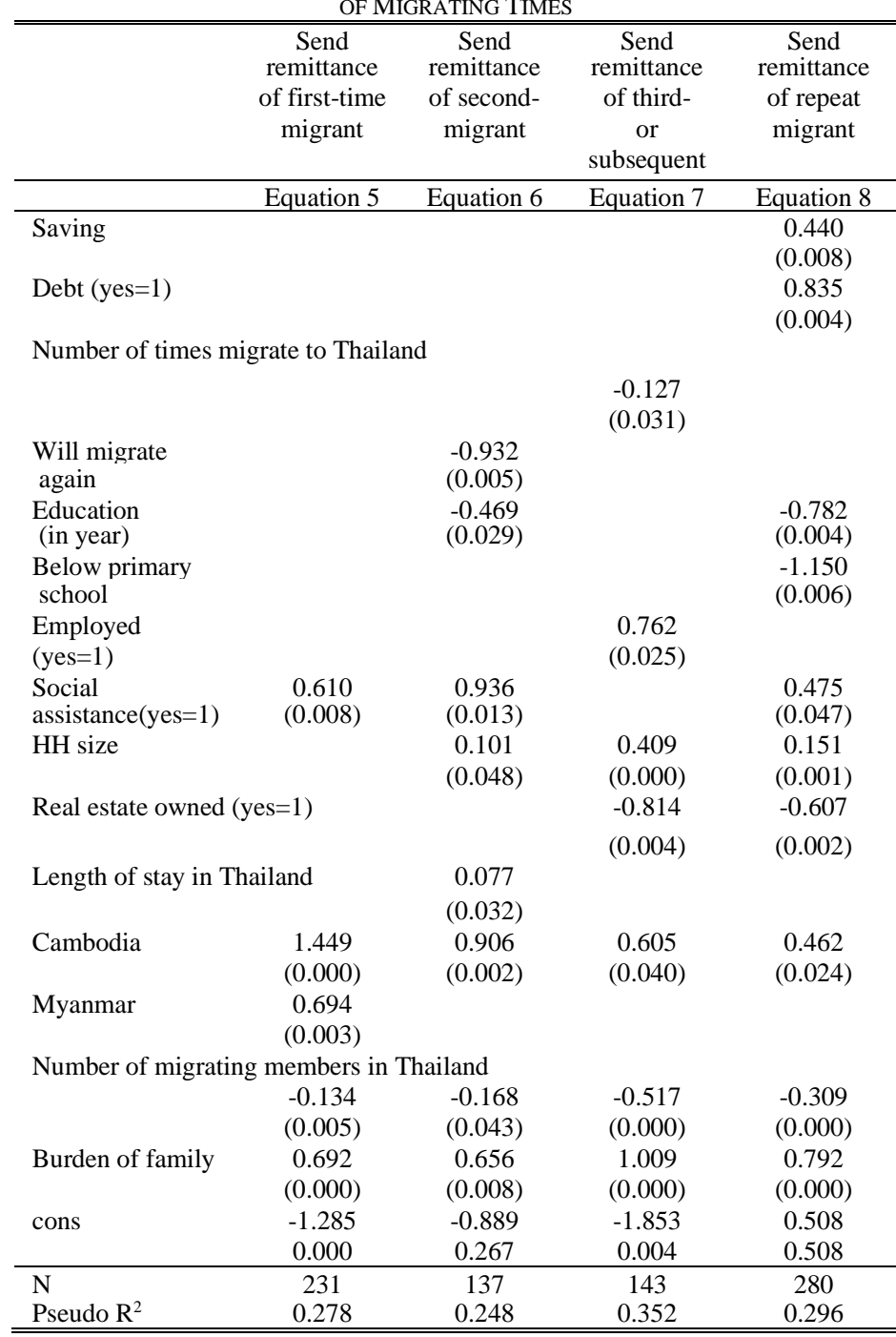

Source: Own calculation.

Note: Value in bracket is $\mathrm{P}>|\mathrm{z}|$.

Table IV presents probit estimation result for remittances. To consider the repeat migration, we reported four sets of results, analyzing send remittances of the first-time migration, second time migration, third time migration and repeat migration as a dependent variable. Equation 5 shows that the send remittances of first-time migrant workers depend on being Cambodian migrants, being Burmese migrants, burden of family, social assistance, and number of migrating members in Thailand. The result indicates a positive relationship between all of these explain variables and remittances, except number of migrating members in Thailand. Comparing the results of equation 6 also reveals that send remittance of second time migrants rely on social assistance, to be Cambodian migrants, burden of family, household size, length of stay in Thailand in same direction. However, remittance of these group relies on aim to migrate again, number year attain school, number of migrating members in Thailand, in opposite direction. Equation 7 illustrates the results including interaction term between send remittances of third time or subsequence migration experience and endogenous variables. The variables that are positive correlated and significant with remittance, are burden of family, being employed, being Cambodian migrant and household size. The other variables that have negative relation to remittances are real estate own, number of migrating members in Thailand, and number of times migrate to Thailand. Finally, the equation 8 indicates that there are four variables, that are, educate below primary school, number of years attain school, real estate owner, and number of migrating members in Thailand, have much more substantial negative effect on the likelihood of sending remittances of repeating migration group. However, five variables (debt, burden of family, social assistance, being Cambodian migrants, saving, and household size) have positive effect on sending remittances of this group. The variable of below primary school plays the highest negative impact on send remittance of repeat migrant. It is explained that education beyond primary school does not increase the probability of sending remittances of repeat migrant. On the one hand, debt play the highest positive impact on send remittance of repeat migrant. The persons who are being in debt, they are more likely to try to earn income and send remittance to repay their debt.

Table $\mathrm{V}$ also briefly examined whether repeat migration depends on the individual's past history of migration. The dependent variable is whether the migrant wants to go abroad again if he or she migrates to Thailand. Equation 9 shows the result of the estimated coefficients for number of migration experience is positive with the occupation of workers who participate in construction sector, number of months visit home in last two years, burden of family, age and saving. It is suggesting that workers in construction sectors are more likely to migrate compared with those who are working in other sectors. It may because this sector requires to hire numerous laborers due to the expansion of Thai economy. Note that the results in equation 10 are quite different from the results in equation 9 , because of the difference in the dependent variable. The results in equation 10 is conditional on repeat migration, while equation 9 examine factors affecting the number of migration experience. It is suggesting that migrants who attain below primary school are the most like to be the repeat migration group.

Table VI shows the estimation results for savings. Equation 11 illustrates the determinants of saving of all migrant group provide the information that being the documented workers are most likely to have less saving because these migrant group must spend a lot of money for registration process and other expenses. In addition, migrants who aim to migrate again in the future, they are less likely to save because they must spend for the international working agency to seek the new working position aboard. Next, migrants who are married but do not have any children, are less likely to save, contradict to the migrants with children are more likely to save for their children. Many estimated coefficients have positive signs to saving, implying the supporting factors on savings are number of visiting homes in last two years, household size, length of stay in Thailand and number of years in Thailand. To begin with workers who visited home in last two years, may have the plan to visit home again in the future, they are more likely to save for returning home. Moreover, workers with large household size have many persons participate in labor force, so they have high ability to save. Finally, workers who have the long length of stay in Thailand and stay in Thailand for many years, they can accumulate a certain savings. Equation 12 
indicates that saving of first-time migrant group depends on two variables, which are age and household size. It can be explained that the older age of first-time migrants is less likely to save because it is difficult for the elders to get a job and they must adjust themselves a lot for survival in the new environment. Lastly, the larger the number of family members mean the higher the probability the members are in working ages, that is why the higher the saving they have. Equation 13 presents the determinants of saving of the second time migrant rely on debt, the desire to migrate again, attain below primary school and single status. Second time migrants who are in debt, are more likely to save and accumulate a certain amount of money to pay loan. At the end, equation 14 discusses about the determinants of saving of third or more times migrants. Six variables influence on saving in the positive ways, are debt, remittance, be Myanmar migrants, number of migrating household member in Thailand, number of months visit home in last two years, and number of years stay in Thailand. The variable that influences on saving of these groups in the opposite way, are single status, be male migrant and number of children.

TABLE V: ESTIMATES FOR REPEAT MIGRATION

\begin{tabular}{|c|c|c|}
\hline & $\begin{array}{c}\text { Number of } \\
\text { migration } \\
\text { (ordered probit) } \\
\text { Equation } 9\end{array}$ & $\begin{array}{c}\text { Repeat } \\
\text { migration } \\
\text { (ordered probit) } \\
\text { Equation } 10\end{array}$ \\
\hline Remittance & $\begin{array}{l}-0.316 \\
(0.010)\end{array}$ & \\
\hline Saving & $\begin{array}{c}0.000 \\
(0.015)\end{array}$ & \\
\hline Age & $\begin{array}{c}0.017 \\
(0.025)\end{array}$ & \\
\hline Education (in year) & & $\begin{array}{c}0.550 \\
(0.001)\end{array}$ \\
\hline Below primary school & & $\begin{array}{c}0.914 \\
(0.000)\end{array}$ \\
\hline Year in Thailand & & $\begin{array}{c}0.040 \\
(0.010)\end{array}$ \\
\hline Employed $($ yes=1) & $\begin{array}{l}-0.399 \\
(0.010)\end{array}$ & \\
\hline Single & $\begin{array}{l}-0.517 \\
(0.000)\end{array}$ & \\
\hline Married, but no kids & $\begin{array}{l}-0.518 \\
(0.003)\end{array}$ & \\
\hline Visit at home in the last 2 years & 0.203 & 0.147 \\
\hline & $(0.000)$ & $(0.005)$ \\
\hline Length of stay in Thailand & $\begin{array}{l}-0.040 \\
(0.005)\end{array}$ & \\
\hline Labor (mostly in construction) & $\begin{array}{c}0.393 \\
(0.001)\end{array}$ & \\
\hline Burden of family & $\begin{array}{c}0.203 \\
(0.038)\end{array}$ & $\begin{array}{c}0.470 \\
(0.000)\end{array}$ \\
\hline cut1 (ordered probit) & 0.095 & 2.898 \\
\hline cut2 (ordered probit) & 0.992 & 3.676 \\
\hline $\mathrm{N}$ & 511 & 280 \\
\hline Pseudo $\mathrm{R}^{2}$ & 0.166 & 0.081 \\
\hline
\end{tabular}

Source: Own calculation.

Note: Value in bracket is $\mathrm{P}>|\mathrm{z}|$.

\begin{tabular}{|c|c|c|c|c|}
\hline & $\begin{array}{l}\text { all } \\
\text { migrants } \\
\text { migrant } \\
\text { group }\end{array}$ & $\begin{array}{l}\text { of first } \\
\text { time } \\
\text { migrant } \\
\text { group }\end{array}$ & $\begin{array}{c}\text { repeat } \\
\text { migrant } \\
\text { (Second time) }\end{array}$ & $\begin{array}{l}\text { repeat } \\
\text { migrant } \\
\text { (third or } \\
\text { more) } \\
\end{array}$ \\
\hline & $\begin{array}{c}\text { Equation } \\
11\end{array}$ & $\begin{array}{c}\text { Equation } \\
12\end{array}$ & Equation 13 & $\begin{array}{c}\text { Equation } \\
14\end{array}$ \\
\hline Remittance & & & & $\begin{array}{r}0.478 \\
(0.000)\end{array}$ \\
\hline Debt & & & $\begin{array}{r}1.874 \\
(0.009)\end{array}$ & $\begin{array}{r}2.444 \\
(0.007)\end{array}$ \\
\hline Single & & & $\begin{array}{l}-0.748 \\
(0.024)\end{array}$ & $\begin{array}{l}-0.877 \\
(0.036)\end{array}$ \\
\hline Will migrate again & $\begin{array}{l}-0.569 \\
(0.000)\end{array}$ & & $\begin{array}{l}-0.882 \\
(0.003)\end{array}$ & \\
\hline Age & & $\begin{array}{l}-0.463 \\
(0.008)\end{array}$ & & \\
\hline Male & & & & $\begin{array}{l}-0.663 \\
(0.019)\end{array}$ \\
\hline Below primary school & & & $\begin{array}{l}-0.820 \\
(0.012)\end{array}$ & \\
\hline Register worker & $\begin{array}{l}-1.066 \\
(0.039)\end{array}$ & & & \\
\hline Number of children & & & & $\begin{array}{l}-0.234 \\
(0.036)\end{array}$ \\
\hline Married, but no kids & $\begin{array}{l}-0.447 \\
(0.035)\end{array}$ & & & \\
\hline HH size & $\begin{array}{r}0.062 \\
(0.004)\end{array}$ & $\begin{array}{r}0.067 \\
(0.017)\end{array}$ & & \\
\hline Year in Thailand & $\begin{array}{r}0.032 \\
(0.016)\end{array}$ & & & $\begin{array}{r}0.136 \\
(0.000)\end{array}$ \\
\hline $\begin{array}{l}\text { Visit home in the } \\
\text { last } 2 \text { years(months) }\end{array}$ & $\begin{array}{r}0.078 \\
(0.005)\end{array}$ & & & $\begin{array}{r}0.179 \\
(0.002)\end{array}$ \\
\hline $\begin{array}{l}\text { Length of stay in } \\
\text { Thailand }\end{array}$ & $\begin{array}{r}0.050 \\
(0.002)\end{array}$ & & & \\
\hline Myanmar (yes=1) & & & & $\begin{array}{r}0.612 \\
(0.035)\end{array}$ \\
\hline Number of migrating & lembers in & ailand & & $\begin{array}{r}0.306 \\
(0.000)\end{array}$ \\
\hline Cons & $\begin{array}{l}-1.211 \\
(0.000)\end{array}$ & $\begin{array}{l}-0.373 \\
(0.152)\end{array}$ & $\begin{array}{l}-0.029 \\
(0.856)\end{array}$ & $\begin{array}{l}-3.120 \\
(0.000)\end{array}$ \\
\hline $\mathrm{N}$ & 511 & 231 & 137 & 143 \\
\hline Pseudo $\mathrm{R}^{2}$ & 0.148 & 0.046 & 0.194 & 0.356 \\
\hline
\end{tabular}

Source: Own calculation.

Note: Value in bracket is $\mathrm{P}>|\mathrm{z}|$.

\section{DISCUSSION AND CONCLUSION}

This study uses a binary dependent variable for migrants' remittance and saving behavior, respectively, indicating whether migrants regularly remit to their family residing in the home country or save for themselves. The migrants are classified into three groups, which are, first time migration $(45.21 \%)$, second times migration $(26.81 \%)$ and third or more times migration (27.98\%). About $58 \%$ of first-time migrants would like to go abroad again, compared with $30 \%$ of second time migrants. This percentage is even higher $(33 \%)$ for thirdtime migrants, suggesting that repeat migration may depend 
on past migration experience. Note to remittance and saving, first-time migrants are most likely to send remittances home while working in Thailand. Saving behavior is similar between first-time migrants and second-time migrants. For first-time and second-time migrants save a portion of their earnings. However, this number dramatically increases to $50 \%$ in the cases of third and subsequent times. The indicator of debts owed is different from the pattern of remittances. Third-time or more times migrants are more likely to have debts and also more likely to send remittances to pay those debts. The average age of migrants is around 28 years for first-time migrants, 31 years for second-time migrants, and 33 years for third- (or subsequent) time migrants. Most of first-time migrants have an education below primary school with $38.96 \%$. Most of the repeat migrants have a primary school diploma. The regression results of the estimates for remittances classified by nationalities. The estimation of sending remittances of all migrant's nationalities. The variables that have the influence on remittances in the same way are the variables of being Cambodia migrants, Burden of family, social assistance, being Myanmar migrant and household size, respectively. On the other hand, the variables that effect on remittances in the opposite ways are attain below primary school, education (in year), real estate owned, and number of migrating household members in Thailand, respectively. The results show that those who finished below primary school are more likely to send remittances, compared with those who finished above primary school. Lastly, the determinants of saving of all migrant group provide the information that being the documented workers are most likely to have less saving because these migrant group must spend a lot of money for registration process and other expenses. In addition, migrants who aim to migrate again in the future, they are less likely to save because they must spend for the international working agency to seek the new working position aboard. Next, migrants who are married but do not have any children, are less likely to save, contradict to the migrants with children are more likely to save for their children. Many estimated coefficients have positive signs to saving, implying the supporting factors on savings are number of visiting homes in last two years, household size, length of stay in Thailand and number of years in Thailand. To begin with workers who visited home in last two years, may have the plan to visit home again in the future, they are more likely to save for returning home. Moreover, workers with large household size have many persons participate in labor force, so they have high ability to save. Finally, workers who have the long length of stay in Thailand and stay in Thailand for many years, they can accumulate a certain savings.

According to the discussion result of this research, the researchers E. Holst and M. Schrooten: pp. 28 [5] identify the variables that influence on remittance of migrants are age, married status, education (in years), employed, and real estate owner, which consistence to equation 1 of this paper that education (in years) and real estate owner have impact on remittance of total migrants. In addition, S. H. Lee, N. Sukrakarn and J.Y. Choi: pp.147 [7] present that significance remittance determinants of first time migrants are number of migration, age, high school, migrant residing in Hong Kong, migrant residing in other countries, and worker in service sector, which are different significance variables from equation 5 of this paper presents that send remittance of firsttime migrants are determined by social assistance, be Cambodian migrants, be Myanmar migrants, number of migrating members in Thailand, and burden of family but it is consistent in the variable of to be the migrant in specific country. Furthermore, this paper consists with the work of S. H. Lee, N. Sukrakarn and J.Y. Choi: pp. 149 [7] those firsttime migrant workers will remit most of their earned income to home. However, S. H. Lee, N. Sukrakarn and J.Y. Choi: pp. 149 [7] express the result that those who finished high schools are more likely to send remittances compared with those who finished primary school, contradict to this research (Table I) have noted that those who finished primary school are more likely to send more remittance than those who completed below primary school. Finally, L. Deelen and P. Vasuprasat: pp. 5 [6] point out that individual incomes, the median income per month at the time of the survey was almost double the income earned when migrants started working in Thailand. Among the three nationalities, the migrant workers from Myanmar received the highest incomes, with a median amount of 6,650 Baht a month at the time of that survey. However, this paper illustrates that migrant earn almost triple income when they started working in Thailand, with average income of 9554 Baht per month. This may as the result of increasing minimum wage policy in Thailand.

The policy recommendations of this research on remittance are as follow. First, Thai commercial bank should decrease the money transferring cost of foreign workers in order to incentive them to do many times of transaction because if there are many times of transfer money, banks also receive the fee of each transaction. Second, government should persuade Thai employers to pay salary through banking accounts and invite migrants to have the long run saving in Thailand. Some migrants may not interest to save in Thailand, but they may interest to buy property or luxury goods instead. So, we should sell product, and persuade to remit things instead of money. Third, government should promote migrants to remit money through formal channels since government can inspect the certain of amount of remittance flow. Fourth, government should promote variety choice of money transfer such as Western Union. Fifth, migrants who switch employer without official consent from Thai authorities will have their status revoked and become irregular migrants. Therefore, they are not brave to remit through formal channel. So, government should allow migrants to switch employers and to move across provinces. Sixth, government should develop innovative financial products for migrants. Finally, government should relax the regulation and allow migrants to bring family members to stay in Thailand to reduce the remittance outflow from Thailand because remittance account for high percentage of GDP. It is better if we can propose the policy for migrants to reinvest their income in country and money still circulate in economic system.

\section{ACKNOWLEDGMENT}

The authors would like to thank Kasetsart University Research and Development Institute (KURDI), Kasetsart 
University, Thailand, for funding this research. In addition, the author also has a special thanks to all migrant workers from Myanmar, Cambodia, and Lao for their kindness to participate the interview

\section{REFERENCES}

[1] World Bank. Migration and Remittances Data. 2019. Retrieved $\begin{array}{llll}\text { February } 1, \quad 2021 . & \text { [Online]. }\end{array}$ https://www.worldbank.org/en/topic/migrationremittancesdiasporaiss ues/brief/migration-remittances-data.

[2] World Bank. Bilateral Remittances Matrix. 2017. Retrieved January 6 , 2021. [Online]. Available: http://www.worldbank.org

[3] S. Turnell, A. Vicary, \& W. Brandford. Migrant-worker Remittances and Burma: An Economic Analysis of Survey Results. In Skidmore, M. and T. Wilson (Eds). Dictatorship, Disorder and Decline in Myanmar. Canberra: ANUE Press, 2008, pp. 63-86.

[4] P. A. Acosta, K. K. Lartey Emmanuel, and F. S. Mandelman. Remittances and the Dutch Disease. Federal Reserve Bank of Atlanta. Working Paper, 2007. No. 2007-8a.

[5] E. Holst, \& M. Schrooten. Migration and Money What Determines Remittances? Evidence from Germany. Discussion Paper Series A No.477. Japan, Tokyo: The Institute of Economic Research, Hitotsubashi University Kunitachi, 2006.

[6] L. Deelen. \& P. Vasuprasat. Migrant Workers' Remittances from Thailand to Cambodia, Lao PDR and Myanmar. Report. ILO/Japan Project on Managing Cross-border Movement of Labor in Southeast Asia, 2010.

[7] S. H. Lee, N. Sukrakarn, \& J. Y. Choi. Repeat Migration and Remittances: Evidence from Thai Migrant Workers. Journal of Asian Economics, 2011, 22(2011), pp. 142-151.

[8] R. Akee, \& D. Kapur. Myanmar Remittances. The International Growth Centre: London School of Economic and Political Science, 2017. Reference Number: S-53405-MYA-1.

[9] OECD. International Migrant Remittances and their Role in Development. 2006. International Migration Outlook: SOPEMI 2006 Edition.

[10] J. Carling. The Determinants of Migrant Remittances. Oxford Review of Economic Policy. 2008, 24(3), pp. 581-598.

[11] U. Oser. Remittances of Guest Workers to their Home Countries: An Econometric Analysis, Diskussions papier Nr. 25, Konstanz: Universität Konstanz, Fakultät für Wirtschaftswissenschaften und Statistik, 1995

[12] D. A. Grigorian., and T. A. Melkonyan. Microeconomic Implications of Remittances in an Overlapping Generations Model with Altruism and Self-interest, 2008. IMF working paper. WP/08/19.

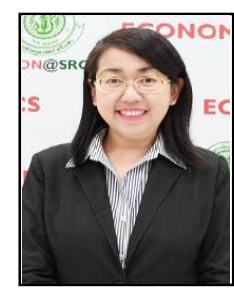

Dr. Thitiwan Sricharoen, Economist (PhDAgricultural Economics) present is an Associate professor of Economics at Faculty of Economics at Sriracha, Kasetsart University, Sriracha Campus, Chonburi, Thailand.

She has developed a number of graduate level courses. Her fields of specialization are International Economics, Development Economics and Agricultural Economics. She is the book's author of International Trade Theory and Policy and International Economic. She has also published many research articles relating to poverty, vulnerability measurement, elderly welfare arrangement, labor migration, impact of unemployment, micro insurance, pattern of paddy storage, and international economy. 